\title{
PUBLIC LAW AND ADMINISTRATION UNDER CONDITIONS OF HYBRID WARFARE (THE EXPERIENCE OF UIRRAINE)
}

\begin{abstract}
Events that took place in Ukraine in 2014 transparently demonstrated the maladjustment of the national legal and administrative system to the challenges of hybrid warfare in times of peace. Although it took into account the possibility of direct military threats, it proved not to be ready for withstanding unconventional pressure. This state of affairs significantly weakened the state's ability to resist and led to a number of dramatic political miscalculations, organizational failures, and acute social problems. The subsequent update of the national public law and administrative system made it possible to improve the situation, but at the same time it revealed a number of pressing issues related to the need to strike a balance between the state's commitment to ensure the protection of human rights and the necessity to protect national security. In this sense the experience of Ukraine is instructive for many countries of the world, especially for those that are the
\end{abstract}

* Taras Gurzhii, Doctor of Law, Prof., Head of Department of Administrative, Financial and Information Law, Kyiv National University of Trade and economics, Kyiv, Ukraine; ORCiD https://orcid.org/0000-0002-3348-8298; e-mail: nosterlex@gmail.com (corresponding author).

** Anna Gurzhii, PhD, Docent, Assoc. Prof. of Department of Administrative, Financial and Information Law, Kyiv National University of Trade and economics, Kyiv, Ukraine; ORCiD http://orcid.org/0000-0001-5757-592X, e-mail: myknteu@gmail.com.

*** dr Adam Jakuszewicz, Instytut Prawa i Ekonomii, Kazimierz Wielki University in Bydgoszcz, Poland; http://orcid.org/ORCiD: 0000-0002-7094-5822, e-mail: jakuszewicz@ukw.edu.pl. 
target of the geopolitical ambitions of the modern Russia. The paper discusses the public law of Ukraine in recent years with the view of highlighting some key problems of legal regulation, as well as identifying some promising ways to develop public administration so that it is capable of effectively coping with the threats of hybrid warfare.

\section{Keywords}

hybrid warfare - hybrid threats - civil conflict - public law - public administration - emergency governing

\section{INTRODUCTION}

The modern paradigm of interstate relations is based on unconditional respect for state sovereignty and an absolute prohibition on the use of military pressure against members of the world community. Any acts of armed aggression are subject to general condemnation and may entail the application of a wide range of political and economic sanctions. In the situation where an open armed attack may entail the attacker's international isolation or loss of markets and vital resources, the direct use of force is increasingly giving way to covert methods of external intervention, such as sabotage, cyberattacks, support of separatist movements, spread of anti-state sentiment, interference with elections, etc.

Given that the need to wage a hybrid war against an external aggressor is a relatively new phenomenon, the legal system of an affected state may not be adjusted to adequately cope with the related challenges. Indeed, legal arrangements may even hamper the authorities in taking adequate and effective measures in the context of hybrid warfare. The inadequacies of the domestic legal system in the face of unconventional forms of pressure may also manifest themselves in legal lacunas, giving rise to the authorities' need to take actions without a sufficient legal basis. A particularly instructive example of such a legal system was (and in part still is) the public law of Ukraine. Although it took into account the possibility of direct military threats, it proved not to be ready for the need to withstand unconventional pressure. This state of affairs significantly weakened the state's ability to take adequate countermeasures to the actions on the part of the Russian Federation and its supporters on the occupied territories. It also led to a number of dra- 
matic political miscalculations, organizational failures, and acute social problems.

The objective of this paper is to identify some key maladjustments of Ukrainian constitutional and administrative law to the challenges of hybrid war, as well as to indicate some directions and guiding principles for its further development aimed at creating appropriate mechanisms for an efficient functioning of the public administration under extraordinary conditions. The main challenges the Ukrainian law-makers face include the need to strike a balance between the state's commitment to ensure the constitutional rights and freedoms of citizens and the necessity to protect national security. The analysis of these issues is preceded by the explanation of the concept of hybrid war and the examination of the influence of the conflict between Russia and Ukraine on its understanding and theoretical development.

\section{The EVolution of the Hybrid WARfare ConcePt: FROM UNCONVENTIONAL GUERRILLA TACTICS TO FULL-SCALE INTERSTATE CONFLICT}

For the description of modern conflicts in which conventional measures are employed along with measures that fall outside the scope of the traditional concept of a military operation, different terms such as unconventional, asymmetric, irregular, or new generation warfare are used in academic and political discourse. However, given the dual nature of such conflicts, i.e. the fact that their parties employ open forms, together with hidden forms of combat and are often assisted by non-state actors, blurring the boundary between war and peace, they are increasingly referred to as hybrid warfare.

The term itself was introduced in 2002 by William J. Nemeth, who used it with reference to the contemporary form of guerrilla warfare, which employs modern technology and modern mobilization methods. ${ }^{1}$ This definition was formulated in the context of the 1st and 2nd Chechen Wars in Russia, that has spawned a lasting guerrilla movement with

${ }^{1}$ J. W. Nemeth, Future War and Chechnya: A Case for Hybrid Warfare, Monterey, CA: Naval Postgraduate School, 2002, p. 41. 
wide use of modern technologies and unconventional means of warfare. According to W. J. Nemeth, the term hybrid warfare is tightly connected with the concept of hybrid society, characterized by a weak central government, distribution of power between local warlords, deep traditional and religious roots, high levels of violence, more so than in pre-state societies owing to the use of modern weapons systems directed at those outside the social group. Struggling for their traditional order, but being unable to resist state forces by conventional means, such societies willingly use all available tactics including kidnapping, control of the enemy's food or water supply, massacres, and blurring the distinction between combatants and non-combatants. ${ }^{2}$ Thus, initially the term hybrid war was referred to the confrontation between state and non-state actors within one state, as well as to the tendency of the latter to use unconventional forms of violence. According to this concept, the term hybrid was applied to give an account of the fragmented society that waged the war rather than to describe the means that were employed in that war.

Subsequent conflicts in Iraq and Afghanistan prompted military experts and scholars to reconsider the initial notion of hybrid warfare as a confrontation between state forces, relying upon conventional methods of warfare, and non-state actors, which use all possible tools, including unconventional ones. The history of confrontation between the Afghan National Army (ANA) and Taliban groups, as well as of the conflict between the Iraqi Army and Security Forces with Ba'athists, Iraqi nationalists, Salafi Islamists, and Shiite organizations has shown the inability of governments to withstand the swarming tactics of rebellions only by regular military operations. As a result, the authorities were forced to hybridize their tactics, which implied involving non-state actors in the fight against insurgents, and to combine regular military operations with measures of economic, informational, and psychological pressure. For instance, as of 2004 only in Iraq 50 private security groups of a total number of 30,000 people were employed to guard officials and installations, train Iraq's army and police, and provide other support. ${ }^{3}$ It

2 Ibid., p. 74.

${ }^{3}$ T. Squitieri, "Role of security companies likely to become more visible", USA Today, April 1, 2004, available at: http://usatoday30.usatoday.com/news/world/ iraq/2004-04-01-security-usat_x.htm [last accessed 7.9.2021]. 
became clear that the state had to turn from the target of hybrid tactics to being an active user of them. This trend has significantly affected the development of doctrinal ideas about the essence of hybrid warfare. Hybrid warfare began to be perceived not so much as a war of rebels free from conventional obligations against a state bounded by such obligations, but as an armed confrontation between the official government and anti-government forces, where both sides can use unconventional means of warfare. As Frank G. Hoffman has noted: "it becomes increasingly perplexing to characterize states as essentially traditional forces, or non-state actors as inherently irregular. Future challenges will present a more complex array of alternative structures and strategies...".

With the recognition of the state as the subject of hybrid tactics of struggle, the term hybrid warfare gradually ceased to be associated with the phenomenon of hybrid society. The hybridity of warfare came to be seen as the result of a combination of military and non-military, conventional and unconventional means of waging it. However, the concept of hybrid warfare continued to be considered in a rather narrow context. In its understanding there prevailed the approach according to which a hybrid warfare: a) was an internal conflict between the official authorities and the insurgents in a particular state; b) was predominantly combative and "incorporated a full range of different modes of warfare including conventional capabilities, irregular tactics and formations, terrorist acts including indiscriminate violence and coercion, and criminal disorder". ${ }^{5}$ The approach in question can be illustrated by the example of a number of definitions formulated at the turn of the first decade of 21st century:

- hybrid warfare includes a combination of irregular warfare, civil war, insurgency, and terrorism that coupled with local conditions blends into a hybrid threat; ${ }^{6}$

${ }^{4}$ G. F. Hoffman, Conflict in the 21st Century: The Rise of Hybrid Wars, Arlington, VA: Potomac Institute for Policy Studies, 2007, p. 8.

${ }^{5}$ Ibid., p. 8.

${ }^{6}$ D. Kilcullen, The Accidental Guerilla: Fighting Small Wars in the Midst of a Big One, Oxford: Oxford University Press, 2009, p. 149-150. 
- warfare is converging and blending into a hybrid form, wherein adversaries will use all the capabilities at their disposal. Both states and non-state actors can conduct hybrid warfare; ${ }^{7}$

- hybrid war is a new form of war, that combines regular and irregular (guerrillas, insurgents, terrorists) forces on the one field that may include both state and non-state actors that are designed to achieve common political goals; 8

- hybrid warfare is a war or a conflict fought by an adversary that uses a mix of conventional weapons, irregular tactics, terrorism, and criminal activities. The hybrid adversary uses this mix to reduce the advantage enjoyed by a conventional army over a smaller force. ${ }^{9}$

The term hybrid warfare was used in this context for more than a decade, until the Russian operation in Crimea and in the East Ukraine in 2014 gave rise to its much broader interpretation. The events that occurred in Ukraine in 2014 led to a common understanding that a state can inspire and conduct hybrid warfare by adopting a large variety of belligerent measures ranging from armed operations to cybernetic attacks, while distancing itself in every way possible from its aggressive policy. The latter is achieved by acting in a surreptitious and indirect manner, as well as by availing itself of non-state actors in politically sensitive areas of activity. “Following the Russian Federation's invasion of Crimea in March 2014 the term hybrid warfare attempts to capture the complexity of 21st-century warfare, which involves a multiplicity of actors, blurs the traditional distinctions between types of armed conflict, and even between war and peace. Although hybrid warfare is a Western term, not Russian, all sorts of hostile Russian activities - from the covert use of special forces to election manipulation and economic coercion - have been labeled hybrid and caused growing alarm in Western security establishments. There are many definitions of hybrid warfare

7 G. F. Hoffman, “Hybrid Warfare and Challenges", Joint Force Quarterly, 2009, №52, p. 34-39.

8 P. Mansur, "Hybrid Warfare in History", in W. Murrey, P. Mansur (eds.), Hybrid Warfare: Fighting Complex Opponents from the Ancient Time to Present, New York: Cambridge University Press, 2012, p. 199.

9 T. Bjerregaard, Hybrid Warfare: A Military Revolution or Revolution in Military Affairs?, Fort Leavenworth: U.S. Army Command and General Staff College, 2012, p. 32. 
and these definitions continue to evolve. Defining hybrid warfare is not just an academic exercise, because these definitions may determine how states perceive and respond to hybrid threats and which government agencies are involved in countering them". ${ }^{10}$

At present this understanding of hybrid warfare prevails in scientific and political thought. Despite the fact that no uniform definition of the term hybrid warfare has been worked out, most scholars in one way or another perceive it as a state policy and activity involving a wide range of state actors, from diplomatic corps to military (and even nuclear) forces. R. Standish defines this concept as "the blending of diplomacy, politics, media, cyberspace, and military force to destabilize and undermine an opponent's government". ${ }^{11}$ According to A. Radin, the term hybrid warfare generally refers to covert actions, supported by the threat or use of conventional and / or nuclear forces, to influence the domestic policy of target countries. ${ }^{12}$ From the point of view of S. Svetoca, hybrid warfare is a conflict in which all instruments of national power, terrorist actions, conventional tactics, unconventional warfare, and criminal acts are resorted to and fused in a single space and time. ${ }^{13}$ In turn, S. Bachmann understands it as "multifaceted method of war where different actors, state and non-state, aim to reach their political or military goals using a mix of conventional and non-conventional, or irregular methods, as well as kinetic and non-kinetic means". ${ }^{14}$

As it can be seen from the above, since the beginning of the Ukrainian crisis the perception of the hybrid warfare concept has evolved, away from the discussion on a novel way of warfare conducted by non-state № 1, p. 7 .

${ }^{10}$ K. J. Wither, "Defining Hybrid Warfare", Journal of European Security Defense, 2020,

11 R. Standish, "Inside a European Center to Combat Russia's Hybrid warfare", Foreign Policy, January 18, 2018, available at: http://foreignpolicy.com/2018/01/18/ inside-a-european-center-to-combat-russias-hybrid-warfare/ [last accessed 7.9.2021].

12 A. Radin, Hybrid warfare in the Baltics. Threats and Potential Responses, Santa Monica, CA: RAND Corporation, 2017, p. 7.

${ }^{13}$ S. Svetoka, Social media as a tool of hybrid warfare, Riga: NATO Strategic Communications Centre of Excellence, 2016, p. 9.

${ }^{14} \mathrm{~S}$. Bachmann, "Hybrid warfare and Lawfare - the use of law as a weapon in the context of hybrid warfare", in Hybrid Threats and Asymmetric Warfare: What to Do?, Stockholm: Swedish Defence University, 2017, p. 39. 
actors to a similarly novel, yet distinct, form of warfare conducted by states, most notably by Russia in Ukraine. ${ }^{15}$

Hybrid warfare in its modern sense and in modern forms is no longer a local confrontation between pro-government and anti-government forces. It is perceived as a full-scale interstate conflict involving massive economic, informational, technical, personnel, and other resources. It is waged by using a large arsenal of combat and non-combat, conventional and unconventional measures, manifested in all key areas of public life.

As the Ukrainian experience has shown, a modern hybrid warfare can be a truly colossal one, involving practically all state and social institutions and affecting the lives of every citizen. These inevitable consequences of hybrid warfare constitute a major concern for both a targeted and an aggressor state. It should be noted that the latter, despite its superiority, is compelled to mobilize enormous human and material resources. Nevertheless, they affect the target state much faster and more painfully by destroying the peaceful model of the life of its population.

Modern hybrid warfare has an equally rapid as wide-reaching impact on the society of the target country. It brings rapid changes in the vital spheres of public relations associated with the country's participation in political, economic, and information confrontation, mobilization of the population, conducting anti-terrorist and military operations, organizing security measures, changing the status of certain territories, and introduction of sanction regimes. The organization of these relations is a priority task of the national system of law. The strategic success in addressing the challenges of the hybrid warfare depends largely on the efficiency and quality of legal responsiveness. Conversely, in conditions of rapid changes in the social situation, the inertia of national law impedes the development of all resistance mechanisms, which ultimately leads to tactical and strategic defeats in key areas of the conflict.

${ }^{15}$ M. Vračar, M. Ćurčić, “The Evolution of European Perception of the Term 'Hybrid warfare'”, Vojno Delo, 2018, № 1, p. 19. 


\section{The Constitutional Foundations of Public ADMINISTRATION UNDER THE HYBRID THREATS}

As has been mentioned above, modern hybrid warfare gives rise to a number of vital challenges to the state and society. Since its beginning, it has gradually undermined the bases of public organization and governance, as well as debilitated the mechanisms of the maintenance of law and order. Successful counteraction to these destructive processes depends to a large extent upon the state legislative policy, on its ability to effectively respond to radical changes in the political, economic, and social situation. Evidently, such a response should be carried out in all areas of law, but above all it is needed on the constitutional level.

As the supreme law that lays the foundations of state and social order, the Constitution is a legal key to solving a great number of largescale problems posed by hybrid warfare. The Constitution and statutes enacted with a view to developing constitutional provisions, called in Ukraine constitutional laws, are the cornerstone of the organization and functioning of state bodies both under ordinary circumstances and in the context of escalating external and internal threats. For this reason, the completeness, clarity, and consistency of constitutional provisions are a necessary guarantee of the efficient and coherent functioning of all management systems, units, and mechanisms designed to ensure national security. On the other hand, the shortcomings of constitutional and statutory regulations, which are hardly visible and seem irrelevant in time of peace, may entail extremely painful consequences in the case of hybrid warfare.

Clear evidence of the adverse effects of the maladjustment of constitutional law to the situation of hybrid warfare is the events in Ukraine in early 2014. At the time of the former President Viktor Yanukovych's escape to the Russian Federation (23-24.02.2014) and the commencement of the occupation of strategically important objects in the Crimean peninsula by Russian troops (02.26.2014), Ukrainian legislation did not provide any procedure governing the President's removal from power (in fact, this made impeachment impossible), nor did it regulate the legal consequences of the President's implicit resignation or self-removal, including issues related to the temporal exercise of presidential 
powers during his absence or incapacity. As a result, already at the initial stage of the hybrid war, the presidential competences could not be exercised so that the military forces were de facto deprived of the commander-in-chief.

The Speaker of the National Parliament (O. Turchinov) was assigned to resuscitate the presidential institution and to perform presidential duties. This emergency measure, however, is to be regarded as extralegal, as it was not covered by any law in force, and so had a very negative effect on the further course of events. Owing to the dubious legality and political volatility of the arrangement in question, the higher ranking state officials felt obliged to make vital decisions related to Russia's annexation of the Crimean peninsula. Despite the clear nature of such an act of aggression, the Ukrainian authorities did not take any military countermeasures. At the same time, Russia started to play the card of the illegitimacy of the Ukrainian authorities on an international level, by questioning both the interim exercise of presidential powers by the Speaker of Parliament and the lawfulness of actions taken by officials appointed by him or subordinated to him, including the Prime Minister and members of the Cabinet of Ministers. For example, when answering a journalist's question about the situation in Ukraine, Russian President Vladimir Putin on March 4, 2014 said the following: "There can be only one assessment of what happened in Kiev, in Ukraine in general. This was an unconstitutional coup and the armed seizure of power... No one argues with this... As for the legitimacy of the current authorities, the Parliament partly is (legitimate), all the rest are not" ${ }^{16}$ Shortly afterwards, this political trump card was used again by Russia as means aimed at instigating the separatist movement in the East of Ukraine, which was originally depicted, not as the struggle for independence, but rather as the resistance to the junta that seized power in the country in the unconstitutional way. ${ }^{17}$

16 Press Briefing by President of Russia Vladimir Putin, The Kremlin, March 4, 2014, available at: http://www.whitehouse.gov/the-press-office/2017/03/16/press-briefingpress-secretary-sean-spicer-3162017-25 [last accessed 7.9.2021].

17 A. Krechetnikov, “Khunta' i 'terroristy': voyna slov Moskvy i Kiyeva” ["Junta" and "Terrorists": War of Words between Moskow and Kyiv], BBC News. Russian Service, April 25, 2014. [in Russian], available at: https://www.bbc.com/russian/ blogs/2014/04/140425_blog_krechetnikov_harsh_speech [last accessed 7.9.2021]. 
From today's perspective, the analysis of the events that took place in Ukraine in 2014 gives enough reasons to assume that the inclusion in the Constitution of detailed regulation of the issues related to temporary exercise of powers of the President would have had a significant, if not radical, impact on the course of events, since it would have resulted in strengthening the position of the authorities and their readiness to confront the hybrid warfare.

However, it is well known that history does not tolerate the subjunctive mood. Owing to the fact that at the first stage of the hybrid war Ukraine was politically, economically, and technically not ready to take countermeasures, it was not able to offer adequate resistance to a largescale complex of hostile acts (covert operations, sabotage, cyberattacks, economic sanctions, riots, and tumults supported from the outside, etc.). The consequences of such unreadiness included, not only great human and economic losses, but also loss of control of central government over considerable territories of the country and of the part of state borders.

The loss of control over a part of the state territory raises the issue of determining its temporary legal status, which includes issues such as establishing lines of delineation and introducing special regimes for the crossing of temporary borders. The solution to these issues is possible, first of all, on the constitutional plane, since it is the Constitution, as well as the statutes and other legislation of the state government, that determines the principles of territorial organization, administrative boundaries, special legal regimes, etc. Decision on the issues in question is considered a subject-matter of constitutional law and a priority of legal policy.

Nevertheless, the Ukrainian experience has shown that the determination of the legal status of the uncontrolled territories in the context of hybrid warfare is a sensitive and complicated issue owing to the changes of borders resulting from the tactical successes and failures of the parties to the confrontation. The fact is that the loss of different regions of the country occurred under essentially different circumstances. While the annexation of Crimea and its inclusion in the Russian Federation was carried out in a quasi-unofficial manner (for a long time Russian authorities did not admit to the participation of Russian military forces in seizure of strategic objects in Crimea), in case of the Donetsk and Luhansk regions the aggressor country distanced itself 
from the events that took place in there (such as seizure of the organs of local and provincial authorities and of the storehouses for weapon by local supporters of the Russian government, the forming of (para)military groups, conducting military actions, conducting referenda concerning the secession of a given territory from Ukraine etc.) by insisting on the internal nature of the conflict and at the same by unofficially providing military, technical and other kinds of support to the separatist forces.

As a result, as far as the annexation of Crimea is concerned, the Ukrainian authorities faced an important dilemma of whether they should become involved in an almost hopeless war or rather hope for a bloodless settlement of the conflict. Eventually they chose a peaceful solution and proclaimed the Peninsula a temporarily occupied territory. In turn, in the case of the self-proclaimed Donetsk and Luhansk People's Republics, the central authorities faced a different dilemma: to recognize them as the scene of large-scale military operations and in consequence declare martial law there, or to look for alternative forms of determining the legal status of the said provinces which would not imply the introduction of a military regime. The authorities opted for the latter and created on the territory of the occupied provinces the so called Anti-Terrorist Zones that originally included some parts of the Donetsk, Luhansk, and Kharkiv regions. Subsequently, some parts of the occupied regions were conferred specific legal regimes (part uncontrolled by government, a controlled part with a special order of military-civilian administration, as well as the line of demarcation, which today includes 114 settlements).

The status of temporarily occupied territories was conferred on some districts of Donetsk and Luhansk regions by virtue of the Law of Ukraine № 2268-VIII of 18 January 2018 “On the peculiarities of the state policy on ensuring the state sovereignty of Ukraine in the temporarily occupied territories in Donetsk and Luhansk regions" ${ }^{18}$ It is noteworthy that it did not happen until 4 years after the actual loss of control over those territories by the Ukrainian authorities. However, the adoption of this Law not only did not solve the problem of the existence of several different zones with specific legal regimes, but also further complicated

18 Law of Ukraine№ 2268-VIII of 18 January 2018 “On the peculiarities of the state policy on ensuring the state sovereignty of Ukraine in the temporarily occupied territories in Donetsk and Luhansk regions", Official Bulletin of Ukraine, 2018, №19, p. 7. 
it. To the above list of such zones were added two more: security zones adjacent to the area of hostilities and areas of national security and defence, and the repulsion and deterrence of the armed aggression of the Russian Federation in Donetsk and Lugansk regions. ${ }^{19}$ Moreover, the Law did not determine the boundaries of these new zones, which created significant risks for both the civilian population and local, national and international organizations, as well as for the media that work in the area of the anti-terrorist operation.

It is obvious that the delineation of several zones of its territory over which central government lost control and which have fundamentally different political status, considerably complicates the implementation of the ordinary constitutional model of social order. This concerns primarily the protection of civil rights and freedoms. Having lost control over a part of its territory, the state is forced to solve the issues of implementation and protection of civil rights and freedoms in the context of various political and legal configurations, which have emerged on the uncontrolled territories, that is, on the occupied territories, and in the territories controlled by the separatist forces. These configurations are fundamentally different both in terms of the peculiarities of legal regulation and in terms of the real state of affairs with regard to the observance of human rights. Each configuration is characterized by its own specific set of problems and legal issues that cannot be solved by applying a single approach. Therefore, there is a need for separate decisions, which would involve the adoption of several legislative acts designed for the particular functioning of a legal regime of a particular territory.

A similar situation is observed in the areas of trade, internal displacement, administration of justice, organization and conduct of elections and referendums, etc. In consequence of the loss of control over certain territories and the establishment of specific political and legal regimes on them, all these areas begin to function at the point of junction, i.e. within different systems: political, legal, economic, and social coordinates. At the same time, the peculiarities of their functioning are so significant that it is very difficult to regulate them in a single legal act, and sometimes it is not possible at all. Thus, the state, which has become the victim of the aggressive hybrid warfare along with the loss of cer-

19 Ibid., p. 7. 
tain territories, necessarily faces the need for a differentiated response (first of all a legislative one) to social, humanitarian, economic, and other challenges. Such a response is an important direction and guarantee of the effectiveness of state legal policy at the constitutional level.

Referring to the state legal policy in the context of hybrid warfare, it should be noted that regardless of its directions, the key issue that requires a constitutional solution is the issue of the restriction on civil rights and freedoms. It is widely accepted that the war on terror requires rebalancing society's needs for freedom and security through mechanisms by which security can be achieved only at the price of freedom. ${ }^{20}$ In conditions of hybrid warfare, where not only the security of individual citizens, but also the future of the entire nation is at stake, the question of temporary limitations of civil rights and freedoms becomes particularly sensitive and acute. Nevertheless, the higher the level of the threat to the state, the greater the willingness on the part of citizens to sacrifice personal freedom in order to save its indivisibility and the very existence.

National legislation seeks to protect both national security and civil liberties, of course, and to strike a fair balance between conflicting values. ${ }^{21}$ Nevertheless, in the case of a serious threat to the state, security interests always prevail. With the exception of non-derogable human rights, such as the freedom from slavery, freedom from torture, or the prohibition of retroactive application of criminal law, the UN recognizes that human rights can be limited or even derogated from in time of national emergency, although the threat should be actual, should imperil the very existence of the nation, and affect the whole population. ${ }^{22}$ In consequence, over the last few years, the Ukrainian authorities have enacted some laws that impose considerable restrictions on freedom of speech, right to public assembly, right to social security, right to privacy

${ }^{20}$ W. Pue, "The War on Terror: Constitutional Governance in a State of Permanent Warfare?", Osgoode Hall Law Journal, 2003, Vol. 41, Issue 2, p. 268.

${ }^{21}$ I. Cotler, "Thinking Outside the Box: Foundational Principles for a Counter-Terrorism Law and Policy", in R. Daniels, P. Macklem, K. Roach (eds.), The Security of Freedom: Essays on Canada's Anti-Terrorism Bill, Toronto: University of Toronto, 2001, p. 111-113.

${ }^{22}$ UN (United Nations) International Norms and Policy Guideline: Human Rights in Times of Emergencies, in International Norms and Standards Relating to Disability, available at: https://www.un.org/esa/socdev/enable/comp210.htm [last accessed 7.9.2021]. 
etc. Many of them can be considered as justified given the instability of the current socio-political situation and the scale of threats to national security. However, the analysis of the practice of such restrictions gives rise to the examination of both the limits of their admissibility and the admissibility of legal forms these restrictions take.

There are also some cases where legislators and law-enforcement bodies interpret permissible restrictions on civil rights and freedoms too broadly (as a rule, in the interests of national security), resulting in the distortion or even negation of their essence. ${ }^{23}$ This is largely owing to the imperfection of their legislative regulation. Despite the fact that the Constitution of Ukraine clearly determines the scope of grounds for limiting the rights and freedoms of citizens and provides for the possibility of such restrictions solely on the basis of a state of emergency, in practice the statutory interference is excessive in the sense that it often goes beyond the scope of the constitutional limitation clause.

For example, the Law of Ukraine № 2268-VIII of 18 January 2018 “On the peculiarities of the state policy on ensuring the state sovereignty of Ukraine in the temporarily occupied territories in Donetsk and Luhansk regions" confers on servicemen and law enforcement officers the power to enter private residential and other premises "in order to ensure the vital interests of society and the state during the repulsion of armed aggression in security zones adjacent to the area of hostilities". ${ }^{24}$ At the same time, Article 30 of the Constitution of Ukraine provides for only one ground for the application of extrajudicial procedure by virtue of which the entry into private housing may be allowed, that is "in urgent cases related to saving lives and property or the direct prosecution of persons suspected of committing a crime". ${ }^{25}$

Since the Constitution has not been adapted to the conditions of hybrid warfare, it envisages the interests of national security as a legiti-

${ }^{23}$ J. Irkha, "Obmezhennia konstytutsiinykh prav i svobod liudyny i hromadianyna $\mathrm{v}$ interesakh natsionalnoi bezpeky Ukrainy v suchasnykh umovakh", [Restrictions on Constitutional Human Rights and Freedoms in the Interest of Ukraine's National Security at the Current Stage], Bulletin of the Constitutional Court of Ukraine, 2015, № 5, p. 78-87, [in Russian], available at: http://nbuv.gov.ua/UJRN/Vksu_2015_5_9 [last accessed 7.9.2021]; V. Seliukov, "Public Administration of Personal Data Protection in Modern Ukraine”, Politické vedy, 2018, №2, p. 138-158; Gurzhii, supra note 27, p. 99-101.

24 Supra note 18, p. 7.

${ }^{25}$ Constitution of Ukraine, Official Bulletin of Ukraine, 2010, №72, Vol. 1, p. 15. 
mate ground for restricting human rights only with regard to: freedom of speech and free expression of one's convictions (Article 34), freedom of association in political parties (Article 36), and freedom of peaceful assembly (Article 39). Restrictions on other rights and freedoms can be allowed only temporarily in case of emergency or martial law (Article 64$){ }^{26}$

Given that in 2014 there was no political will for introducing an emergency regime (Article 83 of the Constitution does not allow the holding of elections of the President and to the Parliament during an emergency regime), and, as well, for introducing martial law (equivalent to a declaration of war), the Ukrainian authorities were forced to exercise judicial flexibility in the questions of limiting civil rights and freedoms. At the same time, the constitutional grounds for restricting rights and freedoms were sacrificed for reasons of political expediency.

Similar restrictions do not always correspond to the scale of social and political problems to be addressed. ${ }^{27}$ The conditions of their legitimacy are not always officially determined, so they are officially always in force. Contrary to the constitutional requirements for compulsory legal registration, they can be regulated by acts of some entities. For example, Resolution of the National Bank of Ukraine №699 of 13 March 2014 "On the application of certain norms of currency legislation during the regime of temporary occupation of the territory of free economic zone 'Crimea'" establishes a rule according to which citizens of Ukraine residing in the Crimea, should be considered as non-residents in Ukraine. ${ }^{28}$ As a result, Crimeans faced a large number of restrictions and prohibitions in the field of banking services. ${ }^{29}$

${ }^{26}$ Ibid., p. 15.

27 T. Gurzhii, "Freedom of Thought v. National Security Interests: the Issues of Hybrid Warfare in Ukraine”, Polityka i Społeczeństwo, 2019, № 1 (17), p. 100.

${ }^{28}$ Resolution of the National Bank of Ukraine № 699 of 13 March 2014 “On the application of certain norms of currency legislation during the regime of temporary occupation of the territory of free economic zone 'Crimea'", Official Bulletin of Ukraine, 2014, № 99, p. 2915.

29 S. Zaets, S. Lunova, O. Fedorova, Vdoskonalennia natsionalnoho zakonodavstva Ukrainy stosovno zakhystu prav liudyny vnutrishno peremishchenykh osib: perehlianutyi bazovyi analiz, [Improvement of the National Legislation of Ukraine on the Protection of Human 
Evidently, in the light of extreme threats to national security that require an urgent response, such deviations from constitutional standards may seem permissible, especially where the existence and fate of the state and nation are at stake. Indeed, the introduction of constitutional amendments and the adoption of relevant laws that concretize them sometimes entails the loss of precious time and the loss of strategic positions in the struggle for the territorial integrity and sovereignty of the state.

However, the negative consequences of such decisions are obvious: they include not only violations of the rights and freedoms of citizens, but also the undermining of the authority of constitutional institutions. As from 2014, Ukraine is one of the leaders in the number of applications filed with the European Court of Human Rights (2014 - 1st place; 2015 - 1st place; 2016 - 1st place; 2017 - 3rd place). Until the beginning of 2017, out of the 80,000 applications submitted to the European Court of Human Rights nearly a quarter $(22.8 \%)$ were filed against Ukraine. ${ }^{30}$ On 25 January 2018, the President of the European Court of Human Rights Guido Raimondi noted in the interview with Evropeys'ka Pravda that about 3800 out of these complaints are directly related to the functioning of the legal regime in the area of the Anti-Terrorist Operations. ${ }^{31}$ In addition, the risk of usurpation of power by individual political forces that exert influence on government decision-making has to be taken into account. The disorderly and unconstitutional nature of the practice of limiting civil rights and freedoms gives rise to using unfair methods of political competition, oppression of the opposition, or suppression of dissenting groups.

Rights of Internally Displaced Persons: Revised Basic Analysis]. Kharkiv: Pravo, 2019, p. 35 [in Ukrainian].

30 O. Golubov, “Sudovyi symptom: chomu Ukraina v liderakh za kilkistiu skarh do YeSP", [Judicial symptom: why Ukraine is the leader in the number of complaints to the EctHR?], Deutche Welle, February 6, 2017, [in Ukrainian], available at: https://p. dw.com/p/2WwoL [last accessed 7.9.2021].

31 "Yevropejs'ky`j Sud z Prav Lyudy`ny` rozglyadaye 3800 skarg proty` Ukrayiny cherez naslidky rosijs'koyi agresiyi", [The European Court of Human Rights is considering 3,800 complaints against Ukraine over the effects of Russian aggression]. Ukrayins`ka pravda, January, 25, 2018, [in Ukrainian], available at: https://www.pravda.com.ua/ news/2018/01/25/7169503/ [last accessed 7.9.2021]. 
The above proves that in the conditions of hybrid warfare (or even in the case of the identification of its threat) an important direction of the state legal policy should be the constitutional recognition of the actual (including the covert) external aggression as a possible basis for limiting civil rights and freedoms in the interests of national security, and the preservation of territorial integrity and sovereignty.

At the same time, at the constitutional level it is important to harmonize the constitutional criteria for the legitimacy of the restriction on rights and freedoms with those provided in the Geneva Conventions, the Universal Declaration of Human Rights, the International Covenant on Civil and Political Rights, the International Covenant on Economic, Social and Cultural Rights, the Siracusa Principles on the Limitation and Derogation Provisions in the International Covenant on Civil and Political Rights, and other fundamental acts of international law.

In particular, it should be stipulated that the relevant restrictions are introduced only in times of a public emergency which threatens the life of the nation. Such a situation occurs where an emergency: (1) is actual or imminent; (2) it affects the whole nation; (3) the continuance of organized life of the community is threatened; (4) The crisis or threat must be exceptional in that the ordinary measures or restrictions are plainly inadequate. ${ }^{32}$ The grounds for limiting rights and freedoms, as well as the procedure for their determination, should be prescribed by law which in turn should be transparent and accessible. The limitations in question should pursue a legitimate aim, be defined as precisely as possible, and be necessary and proportionate to the pursued objective. An important component of controlling the legitimacy of the restrictions on civil rights and freedoms is the development and legislative consolidation of the test for the presence of the above criteria. Such a test should include an accurate, detailed, and exhaustive description of each individual criterion, which will allow the courts to ascertain whether it is present or absent in the actions and decisions of the authorities.

Undoubtedly, the problem of the constitutional responses to the dangers of hybrid warfare is not confined to issues of civil rights and freedoms. Depending on the nature of the impending threats, the pe-

32 Venice Commission (Council of Europe) CDL-AD(2006)015 “On the Protection of Human Rights in emergency situations", March, 2006, available at: https://www.venice. coe.int/webforms/documents/CDL-AD(2006)015.aspx [last accessed 7.9.2021]. 
culiarities of the administrative system, the internal social and political situation, the course of foreign policy, and many other factors, each individual state may face various challenges that must be overcome by way of the amendment to the Constitution. Nevertheless, ensuring human rights and freedoms in all cases will remain the pivotal issue for the domestic legal doctrine, which will determine the prospects for the development not only of constitutional law, but also of all other branches of the law.

\section{AdMINISTRATIVE LAW: IMPLEMENTING THE EMERGENCY GOVERNING}

As a complex social phenomenon, hybrid warfare has a multi-dimensional impact on society. It undermines the very foundations of social life, bringing about destabilization and dramatic changes into a wide spectrum of economic, political, administrative, and many other relations. The organization of these relations relies on different branches of the law. However, a special role in this respect is fulfilled by administrative law, given that it specifies the administrative powers of the agencies of government and: "covers the decision-making process of government administrative units that are part of the national regulatory framework". ${ }^{33}$ Perhaps even more than constitutional law, it frames the interactions between law and politics; it provides the conceptual vocabulary for their transformation over time in response to social change. ${ }^{34}$

As historical experience shows, in the initial stages of hybrid warfare, especially at its hot phase, when changes in public life become kaleidoscopic and the ordinary system of governance begins to fail, there is a need to create special administrative structures capable of uninterruptedly functioning in crisis conditions so that they can promptly react to extreme events and efficiently address urgent social challenges. Such a need exists both on the national and regional levels.

${ }^{33}$ P. Baofu, The Future of Post-Human Law: A Preface to a New Theory of Necessity, Contingency and Justice, Newcastle upon Tyne: Cambridge Scholars Publishing, 2010, p. 30.

${ }^{34}$ S. Rose-Ackerman, P. Lindseth, "Comparative Administrative Law: Outlining a Field of Study", Windsor Yearbook of Access to Justice, 2010, № 28 (2), p. 436. 
In conditions of the destabilization of the administrative system, the emergence of hotbeds of armed conflict, the intensification of terrorist activities, and other threats that occur both in the military and civilian sphere, the question of the operational coordination of public administration, defence, and security issues gains particular importance. This issue is essential owing to the fact that the usual model of inter-agency coordination, when operating under extraordinary circumstances may not prove sufficiently effective. In many countries, it focuses primarily on solving strategic problems, whereas decisions are made in a collegial form by bodies whose meetings are convened on an irregular basis depending on the need (national security councils of European countries serve as a typical example). Since under this model the processes of making organizational decisions are relatively slow, it cannot be applied in the context of sudden challenges of an emergency character. Thus, there is a need to create a special organizational link between decision-making centres of power and administrative structures that would ensure the continuous and effective interaction between them, and that would be endowed with its own set of powers aimed at solving operational tasks of management and security.

And, of course, the creation of such a structure is impossible without a reliable legal basis. Taking this into account, not only during hybrid warfare, but also in the case of the threat of its emergence, the formation of extraordinary coordination and management structures should be an important direction of the state administrative-legal policy. The grounds and procedure for their creation, their place in the system of state authorities, the principles of organization, mechanisms for their supervision, the scope of their competence, the system of security, and any other points important for quick and efficient realization of their activities during hybrid warfare require clear legal definition.

The need for the creation of such structures concerns first of all the realization of tasks related to territories in the zone of armed confrontation. As a rule, on those territories legitimate authorities have been either forcibly liquidated by anti-government forces (territories uncontrolled by the Government) or they become inactive in the sense that they fail to exercise their powers (territories adjacent to the conflict zones where there is a high probability of coming under the control of the opposite party to the conflict) or they operate inefficiently and thus 
hamper the resolution of urgent issues related to defence, security, and governance (controlled by the government of the territory adjacent to the conflict zones). In fact, there is a kind of managerial vacuum-filling of which requires a series of administrative-legal steps, first of all, the enactment of a statute on specific procedure for administration in the zone of armed conflict.

Such an act should consolidate the status of the extraordinary administrative entities (special emphasis should be placed on the elements inherent in the military organization of governance), determine the scope of their competence, formulate their tasks and functions, determine the basics of their formation, subordination, internal organization and interactions between one another, and specify the forms and methods of their activities. At the same time the legislator should pay proper attention to the issues of the transfer of administrative functions and, if appropriate, of the staff and/or some items of property from local authorities functioning in peacetime to extraordinary administrative bodies. Depending on the situation, there can be either delegation of functions to emergency agencies that would operate in parallel with ordinary civil administrative structures, or the complete transfer of powers to the former with concomitant temporary suspension of the activities of the latter. For example, according to the Law of Ukraine № 141-VIII of 3 February 2015 “On Military-Civilian Administrations”, extraordinary authorities are established (of mixed civilian-military character) on the basis of local executive bodies (local state administrations). These newly created entities take over the entirety of functions and powers of local self-government bodies (mayors, local councils, etc.). ${ }^{35}$

Undoubtedly, establishing the extraordinary authorities is an emergency step, which is permissible only under circumstances of largescale threats to national security since it may result in significant restrictions on civil rights and freedoms. This applies both to the very existence of extraordinary bodies (for example, suspension of the functions of self-government authorities entails restrictions on the local community's right to self-government) and to the exercise by them of their competencies (introduction of a curfew, a ban on movement in cer-

${ }^{35}$ Law of Ukraine № 141-VIII of 3 February 2015 “On Military-Civilian Administrations", Official Bulletin of Ukraine, 2015, № 17, p. 7. 
tain areas, confiscation of private property, etc.). In this regard, a statute governing a special procedure for administration in the area affected by armed conflict should explicitly emphasize the temporary nature of the imposed administrative and legal constraints, while guaranteeing the right to judicial appeal against decisions and actions of extraordinary authorities.

In general, this idea should run like a red thread through any act that deals with constitutional rights and freedoms during the hybrid warfare. Under conditions of extreme social crisis and political uncertainty the relevant provisions should not only serve as a tool for regulating social relations, but they should also transmit a message that public authorities are committed to the ideals of democracy, human rights, and the rule of law - a message that should determine the ideological direction of law-making and law enforcement.

When considering the need for the adaptation of administrative law to the conditions of hybrid warfare, it is impossible to ignore the problem of simplifying administrative procedures, in particular those that govern law-making by administrative bodies. It is commonly known that in the modern democratic world, administrative procedures are characterized by detailed regulation, the existence of multi-level control and the involvement of public institutions, which, on the one hand, guarantee their effectiveness, but on the other hand make them rather complex and long-lasting. As for peacetime, such a model of administration is acceptable, since all procedural difficulties are offset by elaborate administrative acts and the maximum protection level of civil rights and freedoms. Contrariwise, in the conditions of an armed conflict that is characterized by a wide range of threats and constant changes in the situation, the issues of the efficiency of administrative decisions come to the fore. The delay of the adoption of a resolution due to procedural requirements may result in extremely negative consequences and in some cases may even jeopardize strategically important facilities and a great number of human lives.

Bearing in mind the above, there is a need to simplify administrative procedures in areas classified as affected by armed conflict. The relevant procedures should be exempted from multilevel approval system, public hearings, and time-consuming forms of public supervision. First of all, simplification should relate to the process of administrative regu- 
lation, which traditionally includes stages such as: the prior publication of drafts of administrative acts, the participation of various specialized bodies in the elaboration of their contents, holding public consultations, etc. Under ordinary circumstances such a procedure may take months, which for obvious reasons cannot be deemed acceptable in a situation of emergency. In emergencies, administrative acts must be adopted and implemented as expeditiously as possible, otherwise they may lose their relevance before they enter into force.

Depending on the peculiarities of the national administrative law, the introduction of simplified administrative procedures can be carried out in different ways, either by amending existing procedural acts or by adopting a special act on administrative procedures to be applied during an emergency period. At the same time, regardless of the legal form they take, the relevant acts should determine the grounds for the application of simplified procedures as precisely as possible and also provide for the possibility of judicial review of decisions taken within their framework.

\section{CONCLUSIONS}

Summarizing the foregoing, in can be affirmed that in the conditions of modern hybrid warfare the targeted state faces fundamentally new challenges characterized by the existent multidimensional threats, intense external pressure, the outbreak of acute social conflicts, the loss of control over territories and strategically important objects, and the need to carry out armed operations under the formal preservation of peace. The realities of hybrid warfare have a profound effect on key spheres of public life, and significantly change the direction of their development. Under such conditions, the effective counteraction to hybrid aggression to a great degree depends on the quality of legal regulation and national system of public administration. A clear example of this is modern Ukraine, which starting from 2014 has been the target of huge scale hybrid aggression. Ukrainian events highlighted the significant influence of law on organizing the nationwide resistance and at the same time exposed a wide range of problems related to the lack of readiness for challenges of hybrid warfare. Drawing on the Ukrainian experience related 
to the impact of hybrid warfare on public law legislation it can be said that law-making policy of a state affected by such challenges should include the following issues:

- the legislative determination of the legal regime related to hybrid intrusion (in particular, the definition of the grounds and procedures for its introduction, the courses of action of state authorities, local self-governing bodies, enterprises and other institutions and organizations; peculiarities of the realization of human and civil rights and freedoms, as well as of the rights and legal interests of legal persons; the principles governing the liability for the infringement of the requirements of the legal regime, etc.);

- determining the criteria for the legality of the restriction on rights and freedoms in the interests of national security, the preservation of territorial integrity and sovereignty, determined on the basis of the fundamental provisions of international law;

- detailed regulation of issues related to the functions of central and local authorities under extraordinary circumstances, in particular, in conditions of sabotage, blocking activities, and self-removal from duties;

- determination of the legal status of certain territories of the state in the case of the loss of control over them by central government, as well as establishing mechanisms for the realization and protection of civil rights and freedoms of the inhabitants of the occupied territories;

- creating mechanisms for the formation and functioning of emergency coordination and management structures aimed at ensuring the exercise of the state power on the lines of delineation and adjacent territories (definition of the legal basis for their creation, principles of organization and subordination, determining their main tasks, functions and powers, as well as of forms and methods of their activity);

- introduction of simplified law-making procedures on territories classified as armed conflict zones (the mechanism of administrative and/or judicial appeal from decisions made under such procedures should be an obligatory element thereof). 